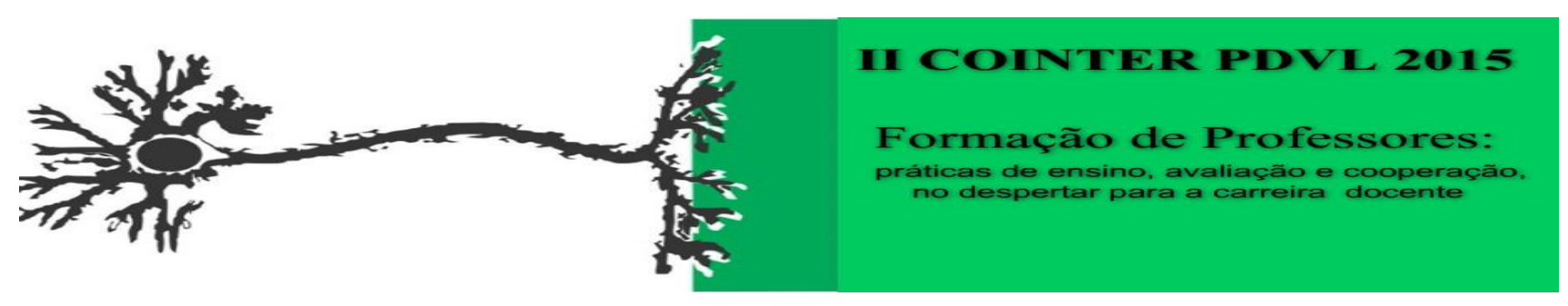

\title{
OS IMPACTOS DAS AÇÕES/ATIVIDADES DO PROJETO NA FORMAÇÃO COMO FUTURO PROFESSOR E NA FORMAÇÃO DOS ESTUDANTES DO ENSINO MÉDIO
}

\author{
Apresentação: Relato de Experiência \\ Eleine Batinga Rodrigues dos Santos ${ }^{1}$; Patrícia Brito Souza da Nóbrega ${ }^{2}$; Johnnatan Duarte \\ de Freitas ${ }^{3}$; Alan John Duarte de Freitas ${ }^{4}$
}

\section{Introdução}

A Química é uma ciência que estuda a matéria e suas transformações, que na maioria das vezes, é vista apenas como uma disciplina decorativa, de difícil assimilação que distancia os conhecimentos químicos da realidade e do cotidiano do aluno. Por causa dessas concepções boa parte dos estudantes, principalmente do ensino médio, não demonstram interesse pela disciplina, ofuscando a curiosidade e o senso investigativo que deveriam demonstrar. De acordo com Alves (2007), no ensino de Química especificamente, a experimentação deve contribuir para a compreensão de conceitos químicos, podendo distinguir duas atividades: a prática e a teoria. Contudo, se torna evidente a importância do professor trabalhar não apenas conceitos teóricos, mas, demonstrar estes conceitos através de atividades experimentais. Com a finalidade de argumentar sobre a importância de atividades práticas ministradas junto às aulas teóricas de química, buscou-se mostrar que a realização de atividades experimentais contribui para a aprendizagem do alunado. Através da aplicação de experimentos, já existentes na literatura, foi perceptível a interação e satisfação dos estudantes em ver que a química vai além de fórmulas e números.

\section{Relato de Experiência}

O Projeto Institucional de Bolsas de Iniciação a Docência - PIBID veio incentivar a formação inicial de futuros profissionais docentes, através da inserção dos graduandos nas escolas estaduais, ou seja, no nosso futuro local de trabalho possibilitando a vivência no que se refere à formação do educador, contribuindo para a elevação da qualidade da nossa formação.

\footnotetext{
${ }^{1}$ Pós graduanda lato sensu em Química Tecnológica, IFAL, eleinerodrigues@hotmail.com

${ }^{2}$ Licenciatura em Química, IFPB, patriciadanobrega@hotmail.com

${ }^{3}$ Prof. Dr. em Química e Biotecnologia, IFAL, johnnatandf@gmail.com

${ }^{4}$ Prof. Dr. em Química e Biotecnologia, IFAL, ajdfifal@gmail.com
} 
Proporcionando o desenvolvimento da prática docente e o aprimoramento de conhecimentos previamente adquiridos. Motivando os alunos de licenciatura em química a serem profissionais criativos, e que busquem sempre uma qualificação dando continuidade ao seu processo de formação, e quando inseridos no mercado de trabalho, possam ter maior segurança na atuação como docente, que também será possível devido à experiência vivenciada no PIBID.

O objetivo do projeto na escola pública é possibilitar aos alunos do ensino médio a compreensão e melhor entendimento da Química, não apenas como disciplina obrigatória do currículo, de vestibulares ou mesmo do Enem (Exame Nacional do Ensino Médio), e sim como ciência central, que além de está ligada a outras áreas de ensino, está diretamente associada com atividades simples do cotidiano do ser humano. Por intermédio da aula experimental, possibilitar aos alunos a construção do conhecimento e dos seus próprios conceitos associando a química ao seu cotidiano com o desenvolvimento de experimentos simples que eles podem fazer com materiais comuns. Dessa forma, o objetivo de contribuir de modo efetivo no processo de ensinoaprendizagem dos alunos foi alcançado, pois conseguiu despertar nos estudantes um senso investigativo e a curiosidade de buscar novas experiências, ouvindo deles que através das aulas experimentais atingiram um maior grau de aprendizagem, comprovando que os resultados das ações foram, além de eficazes, gratificantes.

\section{Considerações}

Além das atividades práticas, o programa possibilitou aos graduandos planejar, elaborar, organizar e executar projetos sociais e interdisciplinares dentro da escola, nos quais, foi possível envolver toda a comunidade escolar (colaboradores/funcionários da escola, alunos e pais de alunos), possibilitando o desenvolvimento de habilidades organizacionais o que contribuiu para o amadurecimento pessoal e profissional do graduando. Entretanto, ao fim da participação no programa pode-se dizer que o mesmo foi de grande valia para formação acadêmica, amadurecimento profissional e pessoal, visto que, este, nos colocou em situações "reais" da prática docente, a falta de estrutura, de materiais didáticos, o dia a dia das escolas, situações "esperadas" e ao mesmo tempo inesperadas as quais o professor vivência no seu local de trabalho. Essa oportunidade de vivenciar e aprender in loco é imprescindível no processo de formação.

\section{Referências}

ALVES, W. F. A formação de professores e as teorias do saber docente: contexto, dúvidas e desafios. Revista Educação e Pesquisa, São Paulo, v. 33. n. 2. p. 263- 280. maio/ago. 2007. 